Selçuk Üniversitesi

İktisadi ve İdari Bilimler Fakültesi

Sosyal Ekonomik Araştırmalar Dergisi

(The Journal of Social Economic Research)

ISSN: 2148 - 3043 / Ekim 2016 / Y11: 16 / Say1: 32

\title{
KÜRESEL DÜNYADA ULUS DEVLET
}

\section{Hülya EŞKİ UĞUZ ${ }^{1}$ \\ Rukiye SAYGILI ${ }^{2}$}

\section{ÖZET}

On sekizinci yüzyılın ürünü olan ulus devlet, günümüzde ortaya çıktığı andan farklı özellikler taşımaktadır. Bu değişikliğin en bilinen nedeni küreselleşme süreci kabul edilmektedir.Bu süreç bir yandan ulus devletin temel niteliklerini yeniden yapılandırmakta öte yandan ise onu kültürel, politik, ekonomik açıdan dönüşmektedir. Bu çalışma söz konusu dönüşüm üzerinedir. Bu bağlamda çalışmada öncelikle ulus devlet formunun tarihsel kökeni, felsefi temelleri ve temel nitelikleri ele alınarak ulus devlet tanımlanmış, ulus devletin küreselleşme özelinde dönüşümü analiz edilmiştir.

Anahtar Kelimeler: Ulus, Devlet, Ulus Devlet, Küreselleşme

\footnotetext{
${ }^{1}$ Selçuk Üniversitesi ïBF Siyaset Bilimi ve Kamu Yönetimi, Doç.Dr.

${ }^{2}$ Selçuk Üniversitesi IïBF Siyaset Bilimi ve Kamu Yönetimi, Arş. Gör.
} 


\section{NATION STATE in GLOBAL WORLD}

\section{ABSTRACT}

The nation state which is the outcome of eighteenth century has different properties today from the moment they occurred. Globalization is considered as the most known cause of this change. This process is both restructuring the basic qualities of nation states and transforming nation-state in terms of cultural, politic and economic turns. This work is based on transformation mentioned. In this context, nation state have been described by dealing with its historical roots, philosophical foundations and basic features and transformation of nation-state based on globalization have been analyzed.

Key Words: Nation, State, Naton State, Globalization

\section{GİRİ̧̧}

Sosyal bilimler yazınında oldukça önemli bir tartışma alanına sahip olan ulus devlet olgusu, modern devlete tekabül etmektedir. Kavramın tarihi ortaçağdan itibaren girift olaylarla açıklansa da hukuki açıdan on sekizinci yüzyılın ilk yarısında ortaya çıktığı genel geçer bir kabuldür. Belirtildiği üzere bu kavramın mevcudiyeti sadece tarihsel bir sürecin sonucunda ortaya çıkmamakta bu tarihselliğine koşut olarak kavramın ilk çağa kadar götürülebilecek bir felsefi boyutu da bulunmaktadır. İkinci Dünya Savaşı sonrasında insanlık tarihinde geçerli devlet formu olarak kabul edilen ulus devlet bir takım niteliklere sahip olmuştur. Bu nitelikler ulusların devlet nezdinde örgütlenmesini sağlayarak ülke sınırlarını teminat altına almakta ve devletlerin varlıklarını sürdürmelerine olanak sağlamaktadır.

Her şeyin akıp durmayacağı ve değişeceği savı ulus devletlerin yirminci yüzyılda karşılaştığı dönüşümü açıklamaktadır. Teknoloji ve ulaşım alanında yaşanan gelişmelere bağıt olarak küreselleşme olgusunun özellikle 1980 sonrasında yayılan etkisi siyasetten ekonomiye, bilimden kültüre birçok alanı derinden etkilemiştir. Bu alanların kesişim noktasında bulunan ulus devletlerde muğlâk ve sonu ön görülemeyen bu olgudan nasibini alarak değişim ve dönüşümün bir parçası haline gelmiştir. Küreselleşmenin kontekstinin birçok zıtlığı barındırması küreselleşmenin etkilerinin olumlu ya da olumsuz değerlendirilmesine yol açmaktadır. Küreselleşmenin ulus devleti güçlendirdiğini düşünerek onu olumlayanlara karş1lık ulus üstü ve ulus altı örgütlenmeler aracıllğıyla ulus devletin egemenliğinin aşındığını ve küreselleşme olgusunun sınırları daha da geçirgen hale getirdiğini belirterek onun olumsuz etkilerinden dem vuranlarda bulunmaktadır. Bu noktada çalışmada ulus devlet nosyonu tanımlanacak, ulus devletin tarihi, felsefesi ve nitelikleri ele alınacak ve nihayetinde herhangi bir tarafın bayraktarlığı yapılmadan küreselleşme neticesinde ulus devlette meydana gelen değişim ve dönüşüm analiz edilecektir.

\section{Ulus ve Devletin (İn)Organik Birlikteliği: Ulus Devlet}

Modern devletlerin ortaya çıkışı ile siyaset bilimi yazınında yer edinen ulus devlet, beşeriyetin son beş yüzyılından itibaren varlığını sürdürmektedir. Ancak ulus devletin ontolojik olarak bu tarihselliğine karşın devlet nosyonun soyutluğu ve ulus devlet formunun uygulanmasındaki farklılıklar, kavramın kesin ve kapsamlı bir tanımını yapmayı güçleştirmektedir. Bu bağlamda ulus devletin irdelenmesi sürecinde karakteristik olarak hem normatif hem de ampirik bir soru sormak mümkündür: "Ulus devlet ne olmalıdır ve neye benzemektedir"? Böylesi bir soru ulus devletin tanımı, devletin yapısı, ilişkileri ve devletin kabul edilebilir sınırlarının ne olduğu hususunda belirli standartlara ulaşmayı kolaylaştırmaktadır. Genel olarak ulus devleti tanımlamaya çalışan gelenekselci akademisyenler devletin açıklayıcı bir değer taşımadığını; davranışsalcıllğı benimseyen akademisyenler ise devletin seküler hükümetler ve siyasi sistemler bütünü olduğunu; post modern düşünürler ise devletin sosyal bilgi ve iktidar alanı içinde faaliyet gösteren bir mekanizmayı yansıttı̆̆ını belirtmektedir (Pierson,2000:20). Bu mütereddit görüşlere rağmen bireylerin hayatına 
bütün bir şekilde nüfuz eden ulus devlet formunun ulus ve devlet saç ayaklarından oluştuğu konusunda bir oydaşma bulunmaktadır.

Ulus devletin tanımlanabilmesi için öncelikle ulus ve devlet kavramlarının ayrı ayrı ele alınması elzemdir. Ancak ulus devletin analizinde olduğu gibi ulus kavramının da tanımlanması; sosyal bilimlerde yoğun bir şekilde incelenmesi(Jaffrelot,1998:54-55), ortak parametrelerin olmamas1, dinamik ve kompleks yapısı vb. nedenlerden ötürü oldukça zordur. Alman Romantizmi'nin yoğun ırk vurgusu ile betimlenen ulus tanımlamalarından, Fransızların teritoryalite ile şekillendirdiği ulus tanımlarına kadar birçok ulus tanımı bulunmaktadır.On üçüncü yüzyılından itibaren kullanılan "doğum, 1rk" anlamına gelen Latince nationemkelimesinden türeyen (www.etymonline.com) ulus kavramı genel manada "etnisitesi, tarihi, kültürü- dili ve dini- birolanvemüradif sınırlar içinde yaşayan insan topluluğu" olarak tanımlamaktadır(Meydan Larousse,1987:418). Mezkûr tanıma göre aynı sınırlar içerisinde yaşayan, aynı simgeleri kullanarak birbirlerine kültürel özellikler ile bağlanan belirgin sayıda insan topluluğu ulusu oluşturmaktadır. Ancak ulusun nasıl oluştuğu konusunda tartışmalar bulunmaktadır. Ulus; "iradeci bir bütünlük mü" yoksa "tasavvur edilmiş bir topluluk mu"? gibi sorular ulus ve ulusçuluk tartışmalarının özünü oluşturmaktadır. Benedict Anderson'a (2007:20) göre ulus, tahayyül edilen bir siyasi topluluk iken, Ernest Renan'a göre ise ulus geçmişten gelen beraberliğe ve milli tarihe konu olan ruha sahip olarak milleti oluşturan kişiler tarafindan sürekli refere edilmesi sonucunda ortaya çıan iradedir(Renan,1996). Bu bağlamda ulus devletin meşruluk ve egemenlik gücünün temelini oluşturan ulus kavramı, sosyalite ve tarih gibi objektif unsurlara önem verse de ulusun sübjektif yanının olduğu yadsınamamaktadır(Esgin,2001:186).

Ulus devletin ikinci saç ayağı olan devlet kavramının kökü "hal, durum" manasına gelen status kelimesinden gelmektedir(www.etymonline.com). Günümüzdeki anlamıylaon beşinci yüzyıl İtalya'sında kullanılmaya başlanmış, on altıncı yüzyılda ise İngilizce karşılığı olan state ile literatürde yerini almışsa da İngiliz düşünürlerin bu kavrama on yedinci yüzyılda daha fazla yer verdiği görülmektedir. ${ }^{3}$ Türkçe'yeArapça'dan geçen devlet kelimesinin İngiliz tarihindeki kullanım sıklığına bağıt şekilde on yedinci yüzyıl itibariyle kullanıldığı anlaşılmaktadır. İktidar ve politik toplumun koruyucusu olarak betimlenen ve tarihsel olarak siyasal füzyonu sağlayan devlet genel manada "belirli bir toprak parçası üzerinde egemen olan belirli bir insan topluluğunun oluşturduğu bir varlık" olarak tanımlanmaktadır(Kapani,2004:35, Gözler,2007:4).Günümüze kadar tahayyül edilen bir çok siyasi yapı formu bulunsa da uygulamada ütopik formların rasyonel şekiller ile sınırlandığı ve bu bağlamda normatiften daha az sayıda siyasi yapı formundan söz edildiği görülmektedir. Söz konusu pre-modern bu formlar "şeflik, polis, imparatorluk, prenslik, krallık, cumhuriyet, hanlık, sultanlık, emirlik, beylik, sultanlık hilafet, diamyo ve shogun" şeklinde sıralanabilmektedir(Yurdusev,2012:6364). Bu bağlamda ulus devletin modern devlet olduğu ifade etmekpek de yanlış bir çıkarsama olmayacaktır.

Ulus ve devletin ayrı ayrı tanımlamasından sonra ulus devletin tanımını yapmak daha da kolaylaşmaktadır. Ulus devlet bireylerin self determinasyon ilkesi ve milli kurumlar doğrultusunda organize ettikleri devlet modelidir. Ulus devlet; aynı etnisiteye, kültürel motiflere, tarihi birikime sahip insan topluluğunun oluşturduğu siyasi formudur. Ulus devlet "kolektivite" vurgusunu barındıran bireylerin milli değerler ile siyasi politikalarını şekillendirdiği siyasi düzen olarak ifade edilmektedir(Özyakışır,2006:78). Leca (1998:13-14) ise ulus devletin tanımını genişleterek onu ulusal

\footnotetext{
${ }^{3}$ Thomas Hobbes "state" kelimesinden daha çok "Leviathana" yer vermiştir. Ayrıntılı bilgi için bknz: Thomas Hobbes, Leviathan, (Çev.SelimLim,İstanbul: Yapı Kredi Yayınları,2001)
} 
bir hükümetin elinde temerküz eden gücü kullanan, yurttaşların her birinin eşitliğini formüle eden ve bunların karar alma sürecine dâhil eden politik bir sistem olarak ele almıştır. Bu tanımların ışığında ulus devleti; ortak maddi ve manevi öğelerin şekillendirdiği, meşruiyeti ulus kaynaklı olan,bireylerin siyasi katılım ile bütünün parçası olduğu bilincine ulaşmasını sağlayan, yasama, yürütme ve yargının yasal bir biçimde sürdürüldüğü bir örgütlenme olarak tanımlamak mümkündür. Ulus devletin kendi sınırları içerisinde yasa yapma, egemenliği elinde bulundurma gücüne sahip olması(Bağçe,1999:6) ve bu gücü istediği yönde kullanması gibi unsurlar ulus devletin teritoryal bir devlet olduğuna işaret etmektedir. Ulus devlet tarihsel belleğe sahip insanlar tarafindan "vatan/ülke" olarak adlandırılan ve sınırları net bir şekilde belirlenen bu topraklar üzerinde bulunan yaşayanların bütün ilişkilerini organize etmesi amacıyla oluş(turul)an bir siyasi varlıktır. Ulus devlet bu sınırlardaki egemenliğini görünür ve algılanabilir kılarak, devleti ve siyasi iktidarı bir araya getirerek, standart bir kültür ile eşit yurttaş yaratarak siyasi merkeziyetçiliği ve toplumsal homojenliği sağlamayı hedeflemektedir. Bu bilgilerin 1 şı̆̆ında ulus devletin milliyetçi projeler sonucunda $\mathrm{m} 1$ yoksa kolektif hafiza ile birbirine bağlanan insanların bu bağı geleceğe taşıma arzusu neticesinde mi şekillendiği diğer bir ifadeyle ulus devletin organik mi inorganik mi bir birliktelik olduğu görecelidir.

\section{Omnium Rerum Principia Parva Sunt ${ }^{4}$ : Westfalian Sistemin Doğuşu}

Ulus devletin daha iyi kavranabilmesi için ulus devletin ontolojisindeetkin olanfaktörlerin irdelenmesi gerekmektedir. Genel olarak geleneksel ulus devletin kökeninin on ikinci yüzylla kadar götürülse de ulusal orduların kurulması ve ulusal bürokrasinin oluşması(Davutoğlu,2003:46) gibi nedenlerle bu siyasi formun -uluslararası ilişkiler disiplini perspektifinden-on yedinci yüzy1lda(Wallerstein,1998:121);-siyaset bilimi perspektifinden ise- Rönesans İtalya'sinda ortaya çıtığı(Yurdusev,2012:68-69) iddia edilmektedir. Fakat 1648 Westfalya Antlaşması ile ulus devlet sisteminin kurumsal temellerinin atıldığ 1 ve buradan tüm Avrupa'ya yayıldığ konusunda literatürde bir konsensüs bulunmaktadır. Avrupa devletlerinin sömürgecilik yarışı içerisinde anlam ifade etmiyor gibi görünse de ulus devletin ülkesellik, egemenlik ve merkezilik özelliklerinin on yedinci yüzyılda ve ulusallık özelliğininiseon sekizinci yüzyılın sonlarına doğru şekillendiği düşünülmektedir. ${ }^{5}$ On dokuzuncu yüzyıl ise milliyetçilik olgusu etrafında kümelenen ulus devletler çağ 1 olmuş, milletlerin devletleşme isteği imparatorlukların toprak kaybetmesine neden olmuştur. Ulus devlet yapılanması İki Dünya Savaşı arasında ve sonrasında meşru devlet formu olarak kabul edilmiştir(Held vd,1999:46, Pierson,2000:70).

\footnotetext{
${ }^{4}$ Cicero’ya ait olan bu söz "Her şeyin küçük bir başlangıcı vardır” manasına gelmektedir. Bu söz ulus devletin ortaya çıkışında paradoks gibi algılansa da tabii biçimde ulus devlet olgusunun gelişimini Westphaliansistemle başlatmak mümkün değildir. Ulus devlet tarihsel, kültürel ve sosyal gelişmelerin sonucunda kümülatif biçimde ortaya çıkmıştır. Bu cümleyi kullanma amacımız, yazındahakim olan görüşten hareketle ulus devletin hukuki miladının Westfalia Barıșı olduğunu vurgulamaktır.

${ }^{5}$ On sekizinci yüzyılın sonlarında meydana gelen Fransız Devrimi ulus devletin gelişimini önemli katkılar sağlamıştır. Fransız devrimi ile oluşun kimlikleşme ve millileşme olgusu tüm Avrupa’yı, ardından ise tüm dünyayı sarmıştır. Fransız Devrimi neticesinde yapılan yeni anayasanın ön gördüğü temel ilkeler üniter/ merkezi bir yapı ve mutlak egemenliktir.
} 
Şekil 1. Ulus Devletin Yıllara Göre Gelişimi(Kaynak:Wimmer ve Min,2006:870)

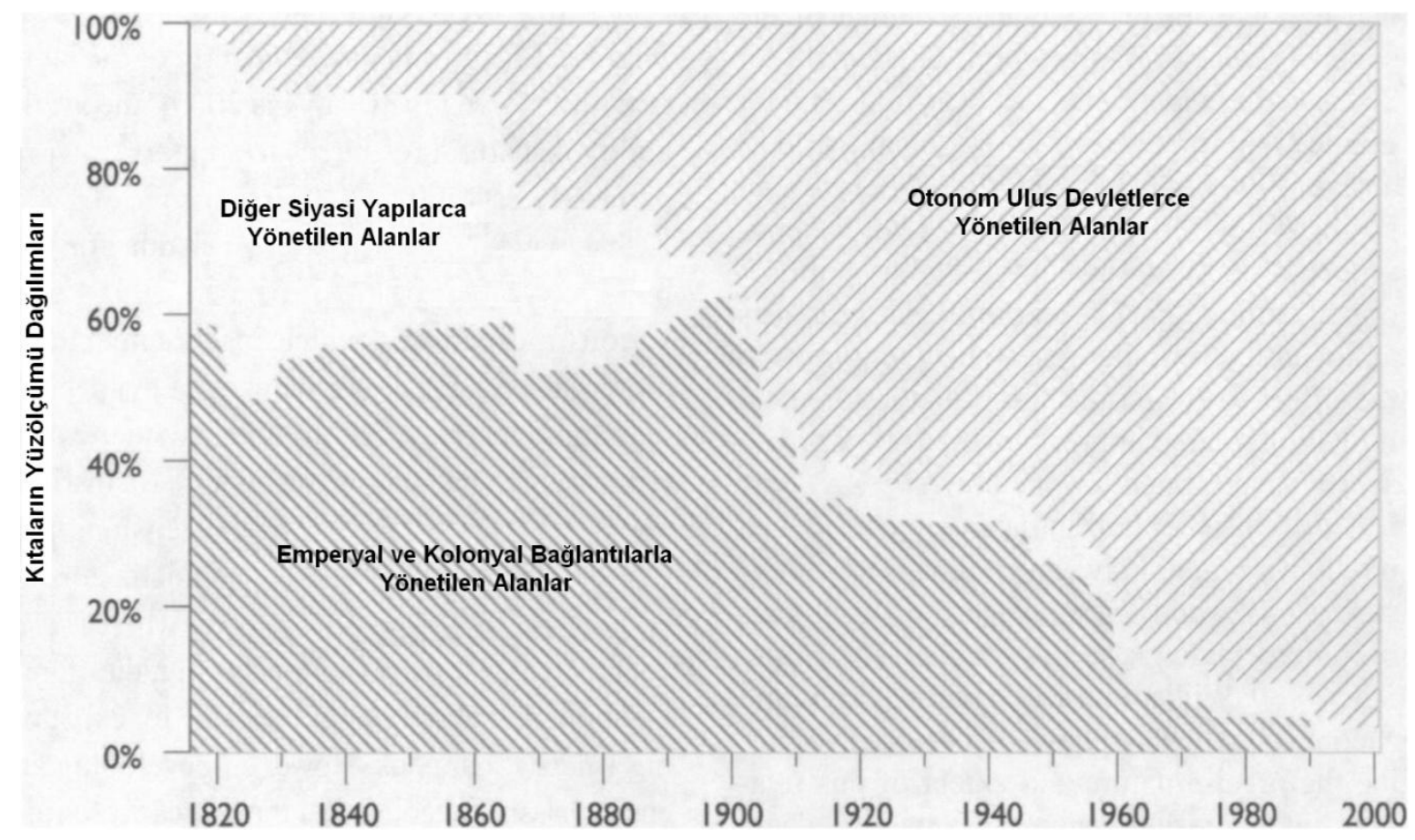

\section{Ulus Devletin Tarihsel Kökeni ve Felsefi Temelleri}

Ulus devlet yazınına baktığımızda ulus devletin ortaya çıkış tarihi Westphalia anlaşması ile somutlaştırılsa da ulus devlet hem fikri hem içtimai hem de tarihi açıdan birçok bileşenden oluşmaktadır. Daha açık bir ifade ile ulus devlet, bugünkü anlamı ve nitelikleri ile ortaçağın bitişi ve yeniçağın başlangıcı arasında Avrupa feodalizminin çözülmesi, mutlak monarklarınsentralizasyonu, Katolik Kilisenin ilahi otoritesinin güç kaybetmesi, merkantilist politikaların sonucunda ortaya çıan kapitalizm, aydınlanma düşüncesi ve milliyetçiliğin gelişmesi, bölünmüş ve konflikt egemenlerin uyruğu altında yaşayan insanlara kesin sınırlar içinde yurttaş statüsünün peyda edilmesi sonucunda doğmuştur(Kapani,2004:42; Ortayl1,2000:11, Bottomore,1987:59). Özetlersek sadakat duygusu ile şekillenen üst bir kimliği ve geçmişten gelen ortak kültürü belirli sınırlar içinde bir egemen gücün himayesinde örgütleyen ulus devlet, bir topluluğun içindeki siyasal bütünlüğü sağlayarak - ki bu suretle ulus adı verilen yeni bir oluşum ortaya çıkmış- asırlar boyu kümülatif şekilde seyreden bir devinimin sonucunda ortaya çıkmıştır. Böylece anakronik devlet tiplerinin meşruiyetini ortadan kaldırarak siyasi, ekonomik, sosyal ve felsefi değişimlere neden olmuştur.

Ulus devletin kuruluşu ile ilgili en bilinen tipoloji Rokkan (1975:570-572) tarafından yapılmıştır. Ona göre insanlık tarihi ulus devleti dört farklı aşama sonucunda oluşturmuştur. İlk aşama; geleneksel devletlerin bulunduğu on beşinci yüzyıldan Fransız devrimine kadar geçen süredir. Haraç alan geleneksel imparatorluklar, feodalizm,zümredüzeni,mutlakiyetçi devletler ve modern devletler olarak klasifike ettiği "beş ana devlet biçiminin" (Pierson,2000:71) ilk dördü ulus devletleşmenin birinci aşamasında yer alan devletlerdir. Söz konusu aşamada yerellik ve akrabalık bağlarından sıyrılarak elitler; ekonomik, siyasi ve kültürel bütünleşme için ilke ve değerler oluşturmaktadır.Ulus devletleşme sürecinin ikinci aşaması kitlenin askeri, teknolojik, siyasi kanallar vasitasıyla yeni sistemin oryantasyonunu içermektedir. Bu aşama da kitlelerin söz konusu kanallar sonucunda yarattı̆̆ yeni kimlik duygusu da önemlidir. Bu yeni kimlik, bölünmüş egemenler ile 
çatışmaya başlamıştır. Uluslaşma sürecinde en önemli adım olarak da niteleyebileceğimiz ü̧̈üncü aşama ise yeni bir kimlik oluşturan toplum üyelerin tebaadan yurttaşa geçişini ifade etmektedir. Söz konusu geçişi kolaylaştıran faktörleri ise muhalefetinoluşması, oy verme hakkının tanınması ve siyasi partilerin örgütlenmesi olarak nitelemek mümkündür. Bu aşamada yurttaşlar genellikle yerelliğin ön plana çıktığıkolektif değerleri bir kenara bırakarak bireysel çıkarları doğrultusunda hareket etmektedir. Daha geniş ifadeyle sanayi ve ulusal devrimlerin yaşandığ 1 bu dönemde kişisel çıkarlarını gerçekleştirmek isteyen bireyler ve egemen güçler arasında çatışma başlamıştır. Ulus devletleşme sürecinin son aşamasını ise idari aygıtların genişlemesi oluşturmaktadır. Bu aşama, siyasetin müşterek kararları alma ve bunları uygulama işlevi neticesinde yönetim olgusunun ortaya çıkması ile tamamlanmaktadır. Ancak, ulus devletleşme süreci her ülkede aynı sıralamayla, aynı hız ve zaman diliminde devam etmemektedir. Bu bağlamda felsefi, siyasi, ekonomik ve tarihi temelleri ile var olan ulus devlet, her coğrafyada birbirinden farklı niteliklere haizdir.

İnsanlık tarihinde geriye doğru baktığımızda, devletlerin varlığı M.Ö.6000'li yıllara kadar götürülmektedir(Tilly,2001:18). Devletin tarihinin bu kadar eski ve yaygın olmasına karşılık ontolojik ve epistemolojik açıdan ulus devletinmodernitenin bir ürünü olarak daha yakın bir çă̆da ortaya çıkması handikap olarak değerlendirilse de ilk çağlardan itibaren ulus devletin bugünkü anlamına ve işleyişine benzer fikri temelleri ilkçağa kadar uzanmaktadır. İnsanı toplumsal-siyasal bir hayvan olarak değerlendiren Aristoteles, insanın temel ihtiyaçları için bir arada yaşayarak ailelerin köye, köylerinde birleşerek "şehir devletine" dönüştüğünü belirtmektedir. Aristoteles'e göre bir devletin oluşabilmesi için insan ve toprak olmak üzere zorunlu iki unsur bulunmaktadır. Nüfus ve yüz ölçümünün sınırlı olması arzu edilen bir durumdur. Devlet toprak bakımından büyük ve nüfus bakımından kalabalık olabilir, ancak bu büyüme devletin ayaklanmalar ve otorite boşluğundan çökmesine neden olabilmektedir(Aristoteles,2005:203-204). Aristoteles'in insan ve ülke vurgusu, ulus devlet kurgusunun ilk prototipidir.

Antik siyaset teorisinde Aristoteles de kökenlerini bulabileceğimiz ulus devlet düşüncesinin modern siyaset bilimindeki yansıması NicollaMachieavelli ile karşımıza çıkmaktadır. "Kötülüğün öğretmeni” olarak da tanınanRönesans İtalya'sının özgün düşünürü Machiavelli, farklı tahayyül ettiği siyasal iktidar düşüncesi ile diğer düşünürlerden ayrılmaktadır. Ona göre siyasi iktidarın temelinde haris, ikiyüzlü, çıkarcı insan doğası bulunmaktadır. İnsan doğası gereği ihtiras ve iktidar peşinde koşmaktadır. Rasyonel düşünen insan, kendi çıkarları peşinde koşarak modern siyasi kuramın temelini de oluşturmaktadır(Ağaoğulları ve Köker,2004a:171,176-179). Machiavelli’nin modern devlet düşüncesinin iyice kavranabilmesi için siyasi iktidarın diğer boyutlarının da irdelenmesi gerekmektedir. Machiavelli'nin prenslik üzerine belirttiği düşünceler, modern ulus devletin niteliklerinin zımni bir anlatımıdır. Machiaevelli, prenslikleri ikiye ayırmaktadır. ${ }^{6}$ Bunlar eski prenslikler ve yeni prensliklerdir. Geleneksel prensliklerden ziyade ulusal birliği sağlayacak güçlü, yeni prensliklerin önemli bir şekilde vurgulandığı görülmektedir. Siyasi iktidarın ve ulusal devletin sağlanması için ilk önce düzenli ordular kurularak merkezi ve egemen bir prenslik kurulmalıdır. Zaten egemen bir prensin halk iktidarını ve desteğini sağlayacağı kesindir(Machiavelli,1994:93).Bu bilgilerin ışı̆̆ında Machiavelli, ulusal ordular ile merkezileşen bir prensliğin, teritoryal alanı ve halkının üzerinde etkin olacağını ön görmektedir. Böylelikle ulusal birlik sağlanacak ve ulusal devlet kurulacaktır.

\footnotetext{
${ }^{6}$ Ayferi Göze(2005:107)'nin aksineAğaoğulları ve Köker (2004:179) prenslikleri dörde ayırmaktadır. Bu iki prenslik çeşidine dinsel ve karma prenslikleri eklemiş̧tir.
} 
Machiavelli’nin çağdaşı Jean Bodin(1530-1596),“Devletin Altı Kitabı” (1576) isimli eserinde açıkçayer verdiği egemenlik kavramı ile ulus devletleşme yolunda önemli bir katkı sağlamıştır. Bodin'e göre devlet, ailelerin ve onların ortak çıkarlarının buyurgan bir güç tarafından doğru ve legal bir şekilde yönetilmesidir(Tuncay,2002:181-183). Bodin egemenlik nosyonu aracılığıyla siyasal iktidarı, iktidarlar arasında en üste yerleştirme çabasındadır. Bu amaç doğrultusunda Bodin egemenliği "superanus" kelimesinden türetmiş ve "devletin bölünmez ve devamlı gücünü” betimlemek için souverainetékavramını kullanmıştır(Andrew, 2011; Kapani,2004:59). Egemenlik, devletin kısıtlanamayan en mutlak gücüdür. Bodin'e göre gücünü Tanrı'dan alan egemen erk, devleti mutlakiyetçiliğe ve birliğe götürerekdiğer topluluk biçimlerinden ayıran en önemli husus ve devlet olmanın birincil koşuludur(Bodin,1969:95). Başka bir ifadeyle "devlet kral" anlayışı çerçevesinde tek bir merkez ile güç bulunduğundan devlet tek egemen tarafından (hükümdar) yönetilmelidir. Egemenlik tektir, mutlaktır, süreklidir, bölünmez- devredilemezdir(Ağaoğulları ve Köker,2004b:2736). Bodin'in kurguladığ 1 egemenlik doktrini; ulus devletin selefi olan ve feodalizmi bertaraf eden mutlak monarşilerin temelini oluşturarak ulusal birliği ve bağımsızlı̆̆ simgelemekte, karma yönetimler ile dini iktidar(lar)1n sonunu getirmektedir(Philpott,2001: 116-117; Göze,2005:126-127). Bu bağlamda Bodin'in, ulus merkezli şekillenecekbir yönetim sisteminin ilk habercilerinden olduğunu ifade etmek yanlış olmayacaktır.

Devlet felsefesinin önemli isimlerden bir tanesi olan Thomas Hobbes'un (1588-1679), düşüncelerine de burada yer verilmelidir.Hobbes'a göre doğa insanları fikren ve bedenen eşit yaratmıştır. Bu insanlar isteklerine ulaşmak için birbirleri ile çatışacaktır. Ancak insanların iç savaşa düşmekten kaçınması için kendileri üzerinde "onları korku içinde tutacak ve onların eylemlerini ortak çıkara yöneltecek bir genel güç” oluşturulmalıdır. Bunu kurmanın yolu ise bütün kudret ve gücün tek bir kişiye ya da bir iradeye indirgeyecek bir heyete devretmeleridir. Başka bir deyişle, Hobbes'a göre bireyler özgürlüklerinin tümünü insan eseri yapay bir yaratık olan otoriter bir egemene teslim etmektedir. Bu bağlamda hükmetme gücünü elinde bulunduran "Leviathan" kudretini rızadan değil, zordan almaktadır. Hobbes'a göre devletin oluşumu, egemen ve uyruklarının baştan belirmesi ile mümkün olmakta ve yabancılar ile vatandaşlardan gelecek saldırılar ve tehditlerden koruyacak üst otoriteye dayanmaktadır. Sözleşme kuramının önemli isimlerinden bir tanesi olan Hobbes, bireylerin güvenliği için egemenlik haklarını devlet gibi mutlak bir otoriteye devretmeleri gerektiğini ön görmektedir. Güvenlik nedeniyle egemenliğin üst otoriteye devredilmesi sonucunda devletin teolojik yapılanma ile ilişkisi kesilecektir(Beriş,2008:58). Sonuçta Hobbes ve Bodin'deki mutlak egemenlik vurgusu, Ortaçağ Avrupa'sında var olan kaotik ve heteronomik görüntü ile ilgilidir. En nihayetinde iki düşünürde toplumu yönetecek egemen birimin nasıl olması gerektiğine işaret etmektedir.

Alman felsefesinin önemli isimlerinden bir tanesi olan George Wilhelm FriederichHegel(1770-1831), özellikle transandantal devlet ve ulus devletin politik bir güce dönüşmesinde eşik taşlarından bir diğeridir.Kimi zaman Hitler gibi bir diktatörün ortaya çıkmasına zemin hazırlamakla suçlanan Hegel, devlet anlayışına büyük önem vermiştir. "Sınır-otorite ilişkisi ve karşılıklı tanınmaya dayalı ulusal egemenlik anlayışı on dokuzuncu yüzyılda özellikle Hegel ile birlikte felsefi bir zemin, bir ruh ve kendi içinde teorik ve sistematik bir bütünlük kazanmıştır" (Davutoğlu,2003:49).Hegel'e göre, insanlar uluslaşmayı becerdiği takdirde devlet de kurulmaktadır. Böylece ortaya çıkan söz konusu aşkın yapıyıHegel, insanlık tarihinin en büyük reformlarından bir tanesi olarak betimlenmektedir(Hegel,2003:162-163). Ziradevlet insanları özgürleştiren formdur.Bireylerin istekleri genelin içinde eriyecek, genelin istekleri için devlet özgürlükleri 
sağlayacaktır. Böylece, insanların bireysel ihtiyaçları azalacak ve toplumsal açıdan ilerleme sağlanacaktır. Hegel'e göre devletin kurucu unsurları; ulusal birliğini sağlamış bir yönetim, karşı gelinemeyecek aşkın bir iktidar ve halktır.

Ulus devletfelsefesine katkı sağlayan isimlerden bir diğeri ise devlet kavramının tanımlama ve analiz etme çabalarında en yetkin kaynak olanMaxWeber'dir(1864-1920) (Gökce,2007:8).Weber (1998: 138), devleti "belli arazi içinde fiziksel şiddetin meşru kullanımını tekelinde (başarıyla) bulunduran insan topluluğu"olarak tanımlamaktadır. Weber, uygulanan bütün yöntemlerin başarısız olma sonuncunda şiddet kullanma hakkının sadece devletlerin hakkı olduğunu vurgulamaktadır(Pierson,2000:26). Başka bir deyişle MaxWeber'e göre modern devleti diğer formlardan farklı kılan unsur " belirli sınırlar" içerisinde "şiddet kullanma tekeli”ni elinde bulundurmasıdır. Weber ulus devletin başka modern bir oluşum olan bürokrasi ile varlığını devam ettirebileceğini düşünmektedir. Siyasi yapının en önemli unsurlarından bir tanesi olan bürokrasi ile devlet merkezileşecek, egemenlik konsolide edilecek ve böylece modern devletin önemli özelliklerinden bir tanesi olan uzmanlaşma sağlanacaktır(Weber,2008:303).

Ulus devletlerin fikri gelişiminde önemli bir isim de AnthonySmith'tir. Smith'in düşünce sistematiğine göre, ulus devlet sadece modernist bir yapı değil, modernist ve pre-modernist yapının birikimi sonucu ortaya çıkmıştır. Smith'in ulus devletleşme süreci milliyetçilikle içkindir. Smith (1991: 14), ulus devletin oluşumunda tarihi anavatan, ortak mitler ve kolektif hafiza, ortak kültür, halkın meşru hakları ve görevleriileteritoryal hareketliliği esas alan ortak ekonomi olmak üzere beş öğenin bulunması gerektiğini ifade etmektedir. ${ }^{7}$

\section{Ulus Devletin Köşe Taşları}

Ulus devletin nitelikleri modern ulus devlet tanımı ile açıklanabilmektedir. Ulus devlet; ülkesellik(teritoryality), egemenlik(sovergnity),merkezilik(centrality), ulusallık(nationality) ile tanımlanan bir siyasi yapıdır(polity)(Yurdusev,2012:64). Bu tanımdan hareketle ulus devletinülkesellik, egemenlik, merkezilik, ulusallık ve siyasi yapıolmak üzere beş ana unsuru bulunmaktadir. $^{8}$

Ulus devletin çerçevesini oluşturan birincil unsurülkesellik/territoryalizmdir. Kesin sinırlarla çevrelenen ulus devlet, sahiplik iddia ettiği bucoğrafialandahilindehükümsürmektedir. Sınırların birbirinden kesin olarak ayrılamaması nedeniyle "ülke" devlet öncesi siyasi örgütlenmelerde tamamlayıc1 ve tanımlayıc1 bir unsur olarak kabul edilmemektedir. $\mathrm{Bu}$ nedenle ulus devletinülkesi,horizontal çizgiler ve egemenlik ile ayrılarak daha önceki örgütlenmelerde mevcut vertikal çatışmaların bulunmadığı alanlardır. Ulus devlet ülkesel bütünlüğü, ortak kültürü, siyaseti, ekonomiyi vs. yurt kavramına bağlı olarak şekillendirme çabasındadır(Beck,2000:23). Çünkü ulus devlet bireylerin dışında egemen olduğu sınırlardan geçen mal, bilgi, finansal ve insan kaynakları vs. ile toplumsal sosyalizasyonu kontrol ederek(Tekeli ve İlkin, 2000: 115) çeşitli düzenlemeleri "suigeneric" ve "domestik" hale getirmektedir.

$\mathrm{Bu}$ unsurların ikincisi egemenliktir. Devletle özdeşleşen egemenlik kavramı, devleti diğer siyasi örgütlenmelerden ayıran genel/nesnel güçtür. Bu güç devletin yasa yapması, bunları uygulamas1 ve sınırları içerisinde karşı gelinemeyecek tek irade olması ile ilişkilidir. Egemenliğin klasik algısı;

\footnotetext{
${ }^{7} \mathrm{Bu}$ öğelerin yanında Smith ulus devlet vurgusunu ulusal kimlik üzerinden geliştirmiştir. Ulusal kimlik ve yukarıdaki öğeler ulus devlet adındaki yönetim biçimini oluşturmaktadır

${ }^{8}$ Pierson, Weberian devlet anlayışına göre ulus devlet mekanizmalarını; ülke,meşru iktidar, egemenlik,meşruiyet, şiddet araçlarının denetimi, anayasallık, kamu bürokrasisi, yurttaşlık olarak ayırmıştır. Ancak yaptığımız beşli klasifikasyon söz konusu mekanizmaları başlıklar altında ele almaktadır. Ayrıntılı bilgi için bknz: Pierson, Modern Devlet, s.24.
} 
egemenliğin mutlak, bölünmez, sınırsız ve devredilmez olduğunu ön görmüştür. Egemenliğin bu şekilde kutsanması, Carl Schmitt'in "devlet teorisi ile ilgili olan her şeyin teolojiden transfer edilmiştir” sözünü hatırlatmaktadır. Modern devlet, "El Şedday’ın”9 yerine, kanun yapma gücünü sağlayan ve devletin temel referansı olan egemenliği monte etmiştir(Özlük,2012:10). O dönemin konjonktürel yapısı, bu kadar güçlü ve keskin söylemleri hazmedebilmiştir. Ancak modern ulus devletler ile klasik egemenlik anlayışında aşınmalar meydana gelmiş, klasik egemenlik yorumu yerini seçimlerle devredilen, kuvvetler ayrılığı ilkesince sınırlı egemenliğe bırakmıştır. Bunun neticesinde egemenlik, siyasal iktidar ile aynı anlamda kullanılmaya başlanmıştır. Devletin gücünü konsolide edebildiği sürece egemenlik her şeyi yapma kudreti değil, devletin egemen sinırları içerisindeki iradesine karşı konulamamasıdır. Söz konusu tarihsel sürecin ulus devlet kendi ülkesi ${ }^{10}$ içerisindeki hareketleri kontrol edebilen, diğer devletler ile karşılıklı tanınma statüsüne bağlı olarak ulusal egemenliğe ve sınır dışı başka egemenlerin müdahale edemediği alana sahip olan yapılanmadır. $\mathrm{Bu}$ bağlamda egemenliği cisimleştirerek(Eken,2006:250) kendisini diğer siyasi örgütlenmelerden farklı kılan günümüz ulus devletlerinin yapısı incelendiğinde bir devletin kamu örgütlenmesini tamamlayarak kontrol mekanizmalarına sahip olan otoritenin kendisinden başka egemen kabul etmediği iç egemenlik; egemen gücün başka devletler ile olan ilişkisini denetleyebildiği ve devletlerin birbirini tanıdığı uluslararası egemenlik; dış güçlerin egemen gücü etkileyemediği Westfalyan egemenlik olmak üzere egemenliğin üç boyutu bulunmaktadır (Davutoğlu,2003:49-50).

Ulus devletin bir diğer unsuru ise merkeziliği gerçekleştirmiş siyasi bir form olmasına dayanmasıdır. Siyasi-ülkesel bütünlüğün sağlanması sonucunda ortaya çıkan ve diğer özellikler içinde üstü örtülü olarak yer alan (Poggi,2007:31) merkeziyetçilik,egemen olduğu sınırlar içerisinde fiziksel zor kullanma tekelini ele geçiren devletin kamu kaynaklarının ve yetkilerin bir elde toplanması anlamına gelmektedir(Bottomore,1987: 61-62; Eryılmaz,2011:88).Ulus devletin merkezileşme serüveni, feodal sistemin çöküşü sonucunda başlamıştır. Ulus devletin selefi olan mutlak monarşilerin kurulması ile devlet olarak nitelenebilecek organizasyon bütünlüğü oluşturulmuştur. $\mathrm{Bu}$ nedenle merkeziyetçilik, devletin devamlılığını sağlayan kamu bürokrasisi ve vergilendirme gibi unsurları da kapsamaktadır. Modern devlet bürokratik bir zemini tesis edebilirse mutlaklığını sağlaması mümkündür. Böylelikle devlet merkeziyetçilik ile siyasi sınırları içerisinde yer alan farklı eylemleri yönlendirebilmekte, gözlemleyebilmekte, etkinleştirebilmekte ve çeşitli yaptırımlar uygulayabilmektedir(Poggi,2007:43). Merkezileşmenin bir diğer unsuru olan vergilendirme, modern devleti feodal öncülünden ayıran en önemli farktır. Mali ihtiyaçlar olmasaydı; düzenli ordular kurulamayacak, sınırlar belirginleşmeyecek, devlet ülkesi ile halkı üzerindeki denetimi ve halkın kendisinden beklediği çıkarları elde edemeyecekti(Tilly,2001:172-174).

Ulus devlet yapılanmasının isminden de anlaşılacağı üzere söz konusu siyasi yapılanmanın belki de en önemli veçhesi ulusallıktır. Toplumsal özgürlük ile egemenliğin en temel göstergesi olan ulusallık, insanları dış baskılardan kurtaran, kesin sınırlar içinde kendilerini ilgilendiren her konuda denetimi elinde tutan, kendi kaderlerini tayin edenbirsiyasal forma imkân vermektedir. Bu formun

\footnotetext{
9 Eski Ahitte Tekvin suresinde geçen bu isim Her şeye kadir olan, gücü yeten“yüce tanrı" demektir. Ayrıntılı bilgi için bknz: (www.tdvia.org)

${ }^{10}$ Egemenlik ve ülkesellik arasındaki girift ilişki, devletin kendisini ulusları ile özdeşleştirmesini ve "sınır fetişizminin" de beraberinde getirmiştir. Çünkü meşruiyetini belirli bir coğrafya üzerinde kurduğu egemenlikten alan ulus devlet, sınırlarını ve toprak bütünlüklerini saldırgan bir kıskançlık ile korumakta, önemsiz bir toprak parçası bile devletin bütünlüğü içerisinde "uğruna ölünecek vatan" olarak değerlendirilmekte ve devletin sübjektif öznesi olan ulusu da bu toprakları ve devleti korumakla görevlendirmektedir. Ülkesellik mekânın zahiri ve batini şekilde kutsallaştırılması ve siyasallaştırılmasıdır. Ancak bu durum, bu topraklar üzerinde yaşayan bireyler ve yönetimleri paranoyak bir hale getirerek bireyleri “ezoterist” vurgu ile şovenizm/faşizme doğru yöneltebilmektedir.
} 
oluşumu, ulusal kültür ve kimlik(leşme) sürecini içinde barındırmaktadır. Ulus devlet bir kültür ve kimlik yaratarak bireylerin kendisini nasıl tanımlayacağını kurgulamakta, bireysel ve kolektif yaşam alanlarını biçimlendirmekte ve bireyleri bu söz konusu kimlik ve kültürün prototipi haline getirmektedir(Hirst ve Thampson,1998:214-215). Bireyleri tek bir kimlik altında toplamak için politikalar oluşturan, başka bir deyişle toplumu homojenize etmeye çalışan ulus devlet bunun için en başta ulusal dili, dini ${ }^{11}$ ve sembolleri“icat ederek" ${ }^{12}$ gittikçe yerleşik bir zemin kazanmaktadır.Sosyopolitik öğelerden başka uluslaşma sürecinde önemli rol oynayan faktörlerden bir diğeri ekonomidir. Ulus devletin ortaya çıkışı, ekonominin önem kazandığı bir tarihsel kapitalizme denk gelmiştir. Feodalizimin çöküşü, coğrafi keşifler, deniz aşırı ticaret gibi gelişmeler sonucunda emek ve sermayede önemli değişiklikler meydana gelmiştir. Toprağın yerini "para", vassal ve serfin yerini ise burjuva ve işçi sınıfı almıştır. Burjuva sınıfı, daha rahat ticaret yapabilmek ve sermaye edinebilmek için, feodal beyler ve kiliseye karşı kralları desteklemiştir. Böylece sermayenin desteğini alan monarklar, aristokrasi karşında zafer kazanmış ve ulus devlet ekonomik gelişme ile zenginleşme açısından en uygun ölçek olmuştur(Uygun,2003:256). Devletler ulusal ekonomi ile dişa bağımlılığı en aza indirgeyerek egemenliğini ve egemenlik alanını pekiştirmekte; kendi üretim güçleriyle ülkenin kalkınmasını ve ekonomik bağımsızlığını sürdürmesini amaçlamakta; milli hedeflerini finanse etmektedir. Tüm bu bilgiler 1şığında siyasi ve ekonomik bir örgütlenme olan ulus devletler,kendi sınırlarında egemen olabilmek için ulusal kimlik, ulusal ekonomi ve ulusal kültürü manivela olarak kullanmaktadır.

Ulus devletin son ayırıcı niteliği ise siyasi yapıdır (polity). Siyasi yapı yurttaşlık, anayasacılık, kamusallık gibi öğeleri barındırmaktadır. Siyasi söylemin en eski örneklerinden bir tanesi olan yurttaşlık, siyasi topluluktaki bireylere eşit haklar, özgürlükler, güçler yanında sinırlılıklar, yükümlülükler ve görevler veren statüdür (Pierson,2000:52-53).Yukarıdadeğindiğimiz ulusal kimlik ile yakından ilişkili olan yurttaşlık; feodal dönemde var olan yerel kimlikleri, siyasi ve ekonomik sistem ile bağlantı kurarak özellikle Fransız devriminin yaydığı milliyetçi bilinçleinşa ettiği ulusallığı, hak ve görevlereulaşma hususunda basamak olarak kullanmıştır.Ancak yurttaşlık, bireylerin kendi başına elde edebileceği bir konum değil, sadece devlet tarafından sadakat koşuluyla bahşedilen bir statüdür. Yurttaşlık modern bir olgudur, zaten Feodalizmin çöküşü, Kapitalizmin yükselmesi, sınıf bilinci ve yurttaşlığın ortaya çıkması aynı enlemde ilerlememiştir. Daha spesifikleştirirsek, ulusların devletleşmesi ile uyrukların vatandaş statüsü kazanması aynı zamana denk gelmektedir. Yurttaşlık; lordların, feodal beylerin egemenliğini ellerinden alarak egemenliği sosyo-politik bütünetaşımıştır. Kapitalizm üretim araçları ile global bir kültür oluşmasına yardımcı olmuş; bireyselliğin doğuşuna katkıda bulunmuş; hükümeti toplum sözleşmesi mantığı içerisinde statüleri belirlemeye zorlamıştır(Sarıbay,1992:91-92). Yurttaşlığın temel parametrelerinden bir tanesi olan kimlik, bir aidiyet sağlayarak insanları diğer insan topluluklarından farklılaştırmakta ve onları siyasi yapı ile topluluğun mensupları haline getirmektedir. Yurttaşlık bağı ile bireyler aidiyeti bulunan devlete sadakat duymakta; devlet açısından ise bu bağ toplumu homojenleştirmekte, yükümlülüklerini belirginleştirmektedir.

\footnotetext{
${ }^{11}$ Devletlerin ortak dini benimseyerek ulus devleti güçlendirmeleri ulus devletleşme süreçlerinin başlangıcında görünmektedir. Avrupa'daki mutlak monarşilerin Kilisenin hegemonyasına karşı başlattıkları mücadelede Lutheryenizm ulusal bütünlüğü sağlayan en önemli katalizörlerden bir tanesidir.

${ }^{12}$ Ulus devlet ulusal kültür üretimini sağlamak amacıyla bayraklar, marşlar, törenler ve gelenekler oluşturmaktadır. Bunun için mitoloji, tarih, coğrafya ve antropolojiden büyük ölçüde yaranılmaktadır. Ayrıntılı bilgi için bknz: James G. Kellas(1991).ThePolitics of NationalismandEthnicity, Londra:MacMillan,EricJ. Hobsbawn ve Terence Ranger(2006).Geleneğin İcadl, İstanbul:Agora Yayıncılık.
} 
Kamusallık ise bağımsız, eşit yurttaşların -farklı kimliğe mensup kişiler olsa da- hiç kimseyi ve hiç bir grubu dışlamamasıdır. Kamusallık insan eseri olan siyasal yapılanmalarda herkes tarafından algılanan, görülebilen ve herkesin hakkıyla yaşayabildiği en geniş açıklığın olduğu bireylerin ortak dünyasıdır(Ardent,2016). Ulus devletin kamusallı̆̆ı; sınıflar, toplumsal grupların yanı sıra dil, din, mezhep, cinsiyet, ırk, etnisite ayrımı yapmadan toplumun siyasal ve toplumsal olarak kutuplaşmaması için tampon görevi üstlenmiştir. Böylelikle kamusallık bireysellikten sıyrılmış en geniş açıklığı sahip, belirsizliği ortadan kaldıran bir süreçtir. Sonuç olarak kamusallık, her türlü farklılık ve ayrımcılık karşısında kolektife vurgusu sonucunda standart bir yaşam tarzını oluşturularak bireyler için gri alanları ortadan kaldırmaktadır.

Anayasacılık, modern devletin dayandığı en önemli felsefi ve fikri temellerden biri olan egemenliğin sınırlandırılmasıdır. Söz konusu sınırlılık bir devletteki üstün hukuk gücüne sahip bir yazılı metin ${ }^{13}$ ile mümkün olmaktadır. Yasalarla değiştirilen idari ve yasal kurumlar/düzenlemeler bütün olarak betimlenen ulus devletleri kendinden önceki siyasi formlardan farklılaştıran bu anayasacılık, sosyo-politik, sosyo-ekonomik farklılıklara, şahsiliği reddeden iktidara ve bürokratik örgütlenmelere yönelmiştir(Pierson,2000:39). Hukukun üstünlüğünü ve kaynağını devlette arayan anayasacılık, ulus devletin merkezinde de bulunarak karşılıklı bir ilişki içerisindedir. Bunun en önemli göstergesi anayasacılı̆̆ın kökeninde yer almaktadır. Ulus devletin oluşumundabireysellik vurgusuna dayanan burjuva sınıfı önemli görevler üstlenmiş̦tir. Söz konusu sınıf,monarklarındilemseluygulamalarını engellemek, kendi hak ve sorumluklarını onlara karşı korumak için uygun reçetenin anayasa olduğunu düşünmüştür. Anayasacıllğ̆ın temeli aslında bir sınıfsal dikotominin yansımasıdır(Flanz,1956:26-27). Bu bağlamda sınıfsal bir amaçla başlasa da anayasacılığın başlangıçtan itibaren temel amacı, keyfiyete karşı koymak, bireysel hak ve özgürlüklerin güvencesini sağlamak, neticede sınırlı bir devlet yaratmaktadır. Sınırlı devlet, modern anayasacılıkla başlamıştır. Esas itibariyle anayasacılık; bireyler ve devletin kurumlarını iktidarın kötü muamelelerinden korumak için çeşitli önlemler almış, karar alma mekanizmasının üzerinde halk egemenliğini sağlamaya ve siyasi aktörleri manipüle etmeye çalışmıştır.

\section{Küreselleşme ve Ulus Devletin Dönüşümü}

Modern devletin ortaya çıktığı on sekizinci yüzyıldan günümüze kadar meydana gelen olaylar ve olgular ulus devletin değişimine ve dönüşümüne neden olmuştur. Ulus devletin meşruiyetini etkileyen en önemli kavram küreselleşmedir. Modernleşmenin getirdiği yenilik anlayışının özellikle son otuz yıldır en önemli yansımalarının yaşandığı küreselleşme, iletişim, ulaşım ve bilgi teknolojilerinde yaşanan gelişmeler sonucunda ortaya çıkmıştır. Mekânsal ve zaman açısından yoğunlaşmayı; hızlı değişim ve dönüşümü; evrensel bir nitelik ile yerel fenomenlerinrölatifleşmesini içeren küreselleşme benzeşme ve farklılaşma unsurlarını bir arada bulundurmaktadır (Marshall, 2005: 449,Capra,2003:112-113, Giddens,1991:5).

Dünyanın mekânsal ve zamansal açıdan daralmasına neden olan küreselleşme ile sınırların geçişkenliğiartmış, iletişim ağları dünyanın her yerine ulaşmış ve global köy ortaya çıkmıştır ${ }^{14}$. Bu ontolojik ve görgül yapı ile entegrist dünya arasındaki mücadele, zamanın mekân karşında zafer kazanması ile son bulmaktadır. Söz konusu galibiyet beraberinde bir taraftan bütünleşmeyi öte yandan

\footnotetext{
${ }^{13}$ Yazılı metin ifadesinin tercih edilmesi ülkemizdeki-Kıta Avrupa'sında- anayasanın bu şekle uygun olmasıdır. Ancak her anayasanın yazılı olduğunu söylemek mümkün değildir. Her anayasa yazılı değildir. Genellikle anglo-sakson modelde anayasalar yazılı değildir-İngiltere anayasası-, yazılıysa bile Kıta Avrupa'sında olduğu gibi kazustik değil çerçeve anayasa-ABD anayasası- niteliğindedir.

${ }^{14}$ 1960'larda Marshall Mcluhan tarafından kullanılan "global köy" kavramı, küreselleşmenin tanımlanması ve zihinlere kazınmasında en bilinen metaforlardandır. Ayrıntılı bilgi için bknz: Marshall McLuhan ve Bruce R. Povers(2001). Global Köy(Çev. Bahar Öcal Düzgören), İstanbul:Scala Yayıncılık.
} 
ayrışmayı ve çözülmeyi getirmektedir. Sınırların deregülasyonu neticesinde uluslararasındaki farklılıklar ortadan kalkmakta, yerel evrensele katkıda bulunmakta; ekonomik, siyasi ve kültürel örüntüler bu süreçte yeniden tanımlanmakta ve nihai olarak evrensel yeni normlar /değer kümeleri ortaya çıkmaktadır (Pieterse,2000:101-102).

Küreselleşme ile birlikte uluslararası sistemde ulus devlet dışında uluslararası örgütler, sivil toplum kuruluşları ve çok uluslu şirketlerin de yer almaları sonucu, sosyal sistemin ekonomi, siyaset, kültür vb. alt sistemleri ${ }^{15}$ yerel/ ulusal nitelikten küresel bir anlayışa geçmiştir. Bu süreçte küreselleşmenin ulus-devleti tehdit eder durumda olduğunu(Esgin,2001:185), ulus devletin küreselleşmeyi kolaylıkla absorbe edeceğini (Sassen,1996:25-30) yada küreselleşmenin devlet otoritelerini tehdit eden bir olgu olmaktan öte teknolojik, ekonomik, siyasi vb. aç1lardan devleti güçlendirerek ona firsat veren bir süreç olduğunu(Tilton,2003:198,Özlük,2012) savunan araştırmacılar bulunmaktadır. Küreselleşme ulus devlet için ister bir tehdit isterse bir firsat olarak görülsün bu tartışmaların neticesinde ortaya çıkan sonuç, küreselleşme olgusu dâhilinde ulusun ve devletin içeriğinin değişmesi (Sarıbay,1998:14-15) nedeniyle ulus devletin değişime ve dönüşüme uğradığıdır.

\subsection{Küreselleşmenin Ulus Devlet Üzerine Ekonomik Etkileri}

Üretimin ve finansal sermayenin ülkeler arasında rahatça el değiştiği küresel ekonomiye geçiş ile birlikte ulus devlet bilimsel anlamda tartışmaya açılmıştır. Ulus devletlerin otoritelerini kaybederek anakronik bir hal aldığını vurgulayan küreselleşme taraftarı yazarlar, küresel sermaye ve piyasanın ulus devletin ekonomik işlevlerini elinden aldığını ileri sürerek ve küresel kapitalizmin önündeki en büyük engeli ulus devlet olarak görerek(Bayar,2008:31) bu tezlerini ispat etmeye çalışmaktadırlar. Ancak kapitalizmin ulus devletle olan tarihi nikâhı, devletin her zaman kendisini yeniden anlamlandırması ve biçimlendirmesi ile sonuçlanmıştır. Kapitalizmin nihai aşaması olan küresel sermaye, baştan itibaren sınırlarını korumak isteyen ulus devleti sermaye ve emek konusunda zorlamış ve sınır geçirgenliğini sağlayacak farklı bağlantı elemanları oluşturmuştur(Brenner,2004:46). İnsanlar, işçi ve girişimci pozisyonunda farklı ülkelerde iş alanlarında görev almış; teknolojik gelişmeler ile bir "tık" uzaklığında ticaret/sanayi sahaları oluşturmuştur.Bunun dışında 1970'li yıllarda Petrol Krizi ile başlayan gelişmeler sonuncunda "yeni dünya düzeni" adı altında düzenlenen ekonomik programlar devletler tarafından uygulamaya konulmuştur. Bu program, devletin asli görevleri dışında özellikle ekonomi gibi alanlardan elini çekerek devletin minimalize edilmesi ve serbestleşmiş pazar ekonomisinin etkinliğinin sağlanması gerekliliği üzerine bina edilmektedir. Böylece milli ekonomiler çöküntüye uğramış, sermaye grupları ulus devletin egemen sınırları içerisinde faaliyet göstermeye başlamıştır. Bu hızlı hareketlilik, ulusal ekonomilerin küresel dünyaya entegre olmasının yanı sıra, dış destekli programlar neticesinde dış borca saplanılabileceği, ithal sanayici bir anlayışı egemen hale getirebileceği, gelir adaletsizliğini artırabileceği, hükümet politikaları ile sermaye piyasalarını olumsuz etkileyebileceği gibi nedenlerle ulus devleti işlevsiz hale getirmekte ve egemenliğin uluslararası kuruluşlar ve çok uluslu şirketler ile paylaşmasına meydan vermektedir(Eken,2006:256,258).Ulusal ve uluslararası ekonomide söz sahibi olan ekonomik uluslararası örgütler, ${ }^{16}$ küresel düzenin oluşturulmas1 ve uygulamaların sorunsuz devam etmesi ve büyük ekonomik depresyonları engellemek gibi nedenlerle ulus devletlerle ilişki kurmaktadır. Uluslararası kuruluşların serbest pazar ekonomisini

\footnotetext{
${ }^{15}$ Söz konusu alt sistemleri tek tek ifade etmek yerine küresel yönetişim kavramını kullanmak tercih edilmiştir.

${ }^{16}$ Küresel örgütler Uluslararası Para Fonu(IMF), Dünya Bankası(DB), Avrupa Birliği(AB), Kuzey Amerika Serbest Ticaret Antlaşması(NAFTA), Orta Avrupa Serbest Ticaret Antlaşması(CEFTA), GATT, DTÖ, OECD, Avrupa Konseyi, APEC, ASEAN, Arap Birliği, İslam İşbirliği Konferansı, Ekonomik İşbirliği Örgütü(ECO), Karadeniz Ekonomik İşbirliği Örgütü(KEİB), Şangay İsbirliği Örgütü, D8, G8 olarak sıralanabilmektedir. Ayrıntılı bilgi için bakınız: Önder Kutlu, Birol Akgün, Şaban Çalış(ed), Uluslararası Örgütler, (Konya:Çizgi Yayınevi, 2006).
} 
geliştirdiği, minimal devlet anlayışını hayata geçirdiği, ekonomik programları yapılandırdığı ve etkinleştirdiği yönünde katkılar sağladığı dile getirilmektedir.Bununla birlikte aslında devletlerin bu örgütlerden destek sağlamak için çeşitli anlaşmalar imzalayıp örgütlere üye olması neticesinde ulus devletlerin söz konusu bağlayıcı hükümler ile egemenlik alanları daralmakta ve devletlerin refah seviyelerinde azalmalar görülmektedir(Cohen,2001:85). Uluslararası kuruluşlardan başka ekonomik küreselleşmede yer alan aktörlerden bir diğeri de çok uluslu şirketlerdir(ÇUS). ÇUS'lar, ulus devletlerin ekonomik faaliyet alanlarında ciddi bir baskı unsuru ve gelişmişlik seviyesinin bel kemiğidir.ÇUS'lar, ulus ötesi/ulus üstü yapısı nedeniyle sermaye hareketliliğini kolayca gerçekleştirebilmekte ve yatırım alanlarını belirleme, ekonomik politikaları etkileme kapasiteleri nedeniyle bu durum çoğu zaman ulus devletler ile sermayedarların çıkarlarının çatışmasına neden olmaktadır. Ancak ÇUS'lar ülkelerin rekabet gücünü artırması, refahı maksimize etmeleri gibi sebepler ile hem faaliyet gösterilen ulus devlete hem de şirkete olumlu katkılar yapmaktadır.

\subsection{Küreselleşmenin Ulus Devlet Üzerine Siyasi Etkileri}

Çok yönlü ve aktörlü niteliğe sahip olan küreselleşme, ulus devletin siyasi işlevlerini de büyük ölçüde etkilemektedir. Küreselleşme ile ulus devletlerin otorite ve bağımsız karar verme yetkisini kaybettiğini, onun siyasal gerginlikleri artırdığını, uluslararası siyasetin altında ezildiğini, devletin kontrol alanını kaybettiğini, gücün zayıf devletlerden güçlü devletlere kaydığını savunan birçok araştırmac1 mevcuttur(Konak,2011:152). Bu görüşler doğrultusunda insan ilişkilerini sınır üstü bir şekle dönüştüren küreselleşme,ulus devletlerin sınırlarının öneminin azalmasına ve sınır aşan yapısıyla ulus devletlerin egemenliklerinin erozyona uğramasına neden olmaktadır. Bütün bu gelişmeler neticesinde ülkesel sınırlar gittikçe belirsizleşmekte ve evrenselile yerelin aynı anda yükselmesine sebep olmaktadır. Küreselleşme, yerelin sona ereceği beklentisini beraberinde getirse de -milliyetçilik bağlamında- yerellikte niteliksel ve niceliksel değişmeler söz konusudur. Global milliyetçiliğinin üçlü bir klasifikasyonu bulunmaktadır. Bunlar(Eken,2006:260):

1. Mahiyet bağlamında milliyetçilik özelliği taşımayan hareketler(Yugoslayva'nın dağılma sürecinde ortaya çıkan milliyetçilik)

2. Gerçekleşmesi gereken zamanda ortaya çıkmayan milliyetçilikler(Sovyetlerin çökmesi sonucu ortaya çıkan milliyetçilik)

3. Azınlık milliyetçilikleri

Küreselleşme milliyetçiliği, klasik milliyetçilik anlayışından oldukça farklıdır. Bir bağımsızlık mücadelesinden önce küresel milliyetçilik, kimlik milliyetçiliğidir. Kimliğin bu denli yükselişi, onun meşru siyasi formu ulus devletin önemini korumasına ve etkin bir aktör olarak siyasi sistemde varlığını sürdürmesine neden olmaktadır.

Siyasi küreselleşmenin getirdiği bir diğer sonuç ise demokrasi söylemidir. Küreselleşme, bir yandan demokrasinin taşıyıcısı öte yandan demokrasinin handikapı olarak siyaset ajandasında yerini almaktadır. Soğuk savaşın bitişi ile zaferini ilan eden siyasal liberalizm/neo-liberal politikalar, küresel siyasetin temel ideolojisive küresel kurumsallaşmanın tek ölçütü haline gelmiştir. Bireysel özgürlüklerin devlete karşı güvence altına alınması, anayasa ile devletin sınırlandırılması, sivil toplumun etkin bir şekilde siyasi hayatta yer alması, siyasi katılım vb. uygulamalar küreselleşme neticesinde bütün ülkelere yayılmış ve demokratik yönetimin bulunduğu ülkelerde ise demokrasiyi konsolide etmiştir. Söz konusu bu katkıların yanında küresel demokrasi, hukuk devleti ile birey hak ve özgürlük açısından halk egemenliğini zapt-1 rapt altına aldığı, gelişmekte olan ve az gelişmiş ülkeleri özellikle uluslararası kuruluşların dış etkilerine maruz bıraktığı gibi hususlarda eleştirilebilmektedir. 
$\mathrm{Bu}$ durum, küreselleşmenin ulus devletler ile uluslararası kuruluşlar ${ }^{17}$ arasında sağladığı egemenlik devri neticesinde ortaya çıkan meşruiyet krizleri ile devletin yerel coğrafyasını aşındıran ve yeni bölgesel politikaların oluşumu ile ilişkilendirilen post-militarizm(Le Gales,2006:718-719) ile açıklanmaktadır. Küreselleşme söz konusu kuruluşlar ile ulus devletlerin milli politikaları üzerinde güç elde etmekte, artan bağımlılık ile milli egemenlik kavramının içini boşaltmaktadır(Şahin,2009:102). Burada ulus devletleri siyasal açıdan küreselleşmeden başka üç faktör daha tehdit etmektedir. Devleti güçlendirdiği noktalar bulunsa da ulus devletleri zayıf ve savunmasız bırakan faktörler şunlardır(Özlük,2012:86):

- Küresel bir nitelik kazanan güvenlik açığı/ güvensizlik

- Ulus devletin kendi başına çözüm üretemediği demografik ve çevresel etkiler

- Yeni unsurlar ile ulus devletin siyasa yapım sürecini etkileyen kimlik politikaları

Küreselleşmenin ulus devlet üzerinde aşındırıcı bir etkiye sahip olduğu görünen bir gerçektir. Ancak bu tehditlere rağmen ulus devletin reel manada hiçbir zaman tam bir şekilde egemen olmadığı için küreselleşmenin ulus devleti güçlendiren bir olgu olduğunu ve bu nedenle küreselleşmenin ulus devlet için bir tehdit değil bir firsat olduğunu düşünen araştırmacıların sayısı da azımsanmayacak orandadır.

\subsection{Küreselleşmenin Ulus Devlet Üzerine Kültürel Etkileri}

Küreselleşmenin ulus devleti dönüştürdüğü bir diğer alan ise sosyo - kültürel yapıdır. Sosyal sistem, ekonomik özellikler, siyasi olaylar ve analizler, tarihî geçirgenlik, kültür ve zihniyet dünyası, coğrafi özellikler, inanış biçimleri vb. öğeleri içerisinde barındırması ve genel bütün içerisindeki işlevinin değişkenliği nedeniyle aslında küreselleşmeden etkilenen en önemli alandır. İnternet, medya şirketleri ve teknolojik gelişmeler(Talas ve Kaya,2007:154) tarafından desteklenen kültürel küreselleşme(McDonald'slaştırma), herhangi bir yerde üretilen bilgi, mal,değer ve imajların uluslararası ve kültürler arasındaki farklılıkları ortadan kaldırma sürecidir(Heywood,2013:191). Kültürel küreselleşme, kültürlerin kendi simgeleri ve sembolleri aracılığıyla oluşmakta, homojen bir alg1 içerisinde şekillenmektedir. Başka bir deyişle kültürel sıkışma içerisinde farklı kültürler beraber yoğrulmaktadır(Eken,2006:259). Bunun neticesinde ortaya çıkan çok kültürlülük, sınırları ve kimlik kavramını derinden sarsmakta; mikro milliyetlerin, kurgusal küçük grupların(cemaat, cinsiyet, din, dil) ortaya çıkmasını sağlayarak homojen ve üniter ulus devlete partiküler ve heterojen bir yapı öngörmektedir. Daha spesifik şekli ile kültürel küreselleşme, ulus devletin homojenleştirici ve tek düze niteliğini heterojen ve dinamik bir hale getirmektedir. Söz konusu farklılıkların girift ilişkisi, ulus devletin ulusal/milliyetçi yapısını aşındırarak mekânsal kimliklerin yerini farklı kimliklere bırakmasına, aşkın şekli ile ulus devletin kimlik yaratma imtiyazını sivil toplum kuruluşlarına ${ }^{18}$ devretmesine ve ulus devletin globalleşerek birbirlerine benzemesine neden olmaktadır. Böylelikle kültürel küreselleşme homojenleşen bir dünya ve kültür oluşturarak ulus devletler açısından bir yandan erime potası(melting pot) işlevi görürken diğer yandan kültürel yozlaşmayı da beraberinde getirmektedir.Bir başka deyiş̧le ulus devletlerin karşılıklı etkileşimi sonucu oluşan küresel kimlik, milli kimlikleri aşındırarak kimlik krizleri yaratmakta ve dini,etnik, yerel, cinsiyet eksenli kimlik

\footnotetext{
${ }^{17}$ Küreselleşmenin ekonomik etkilerini incelediğimiz bölümde, söz konusu örgütler sıralandırılmıştır. Artık küresel siyaset neticesinde bu örgütler sadece bir alan üzerinde uzmanlaşmamakta, ülkelerin siyasi, ekonomik, kültürel vs. alanlarında da faaliyet göstermektedir.

${ }^{18}$ Uluslararası siyaset ve küreselleşmenin üçüncü aktörü olan sivil toplum kuruluşları, hükümetin organizasyonel yapısı haricinde faaliyet gösteren, kar amacı gütmeyen ve gönüllük esasına dayanan organizasyonlardır. Devletin karmaşık sorunları çözmedeki yetersizliği karşısında ortaya çıkmıştır. Küresel sivil toplum kuruluşları dünyanın bir çok noktasında faaliyet göstermekte ve özellikle siyasal, toplumsal ve ekonomik sorunlar, çevresel felaketler, sosyal yardım, insani yardım ve insani güvenlik vs. faaliyet alanlarında, siyasal ve sosyal açıdan daha arzulanabilir bir dünya yaratmak istemektedir. Hükümetler, uluslararası kuruluşlara göre daha zayıf olan sivil toplum örgütleri, Dünya Bankası, AB gibi uluslararası kuruluşlar tarafından desteklenerek siyasi, sosyal ve mali politika inşasında önemli bir manivela işlevi görmektedir.
} 
enflasyonu oluşturarak alt kimliklerin ön plana çıkmasını sağlamaktadır. Küreselleşmenin bir diğer sosyal etkisi ise popüler kültür sonucu ortaya çıkan tüketim toplumudur. Mezkûr olgusunun yayılmas1 sonucunda bireyler, mental yapıları, beşeri ilişkileri ve dış görünüşlerinde farklı bir yaşam tarzı dizayn etmekte ve birbirlerine daha çok benzemektedirler. İnsanlar ihtiyaç dışı bir ürünü trend ya da moda adına satın almakta, kendilerini bu sayede toplumda daha itibarlı hissetmekte ve popüler kültürün bir parçası haline gelmektedir. $\mathrm{Bu}$ durum sosyo-psikolojik ve sosyo-dini açıdan; değer/tevekkül duygusunun yitimini artırmakta; ekonomik açıdan ise bireyin daha fazla para harcayarak küresel ekonomiye katkı yapmasını sağlamaktadır.

Kısaca, kimi zaman lanetlenen/ yeni kolonyalizm olarak adlandırılan kimi zaman ise günümüz dünyasının "sinequanonu" olarak tasvir edilen küreselleşme, Batı değerlerinin ve üstünlüğünün dünyaya yayılmasıdır. Günümüz devletlerinin geleneksel siyasi kurumları, yapıları, ulusal bilinci vs. teknolojik dönüşüm ve ekonomik entegrasyon ile değişmekte; zaman ve mekan önemini yitirmekte; ulusal/kollektif olan yerini mahalli, ferdi olana birakmakta; ekonomiyi ve bireyleri vatansızlaştırmakta; kendi kurum ve değerlerini inşa etmekte; ortak simgeler ve standart formlar ile "dünya yurttaşlığı"yaratarak farklı kültürlerin ürünleri olan farklı toplumların gittikçe birbirine benzemesine neden olmaktadır.

\section{Ulus Devletin Geleceği}

Ulus devletin zaman içinde sonu mu gelecek yoksa ulus devlet önemini kaybetmeden egemenlik ve sınırlarını yeniden mi tanımlayacak?Küreselleşmenin etkisini derinden hissedilmeye başlandığı zaman Sassen'in(1996:85) sorduğu bu sorular, küreselleşmenin tüm hızıyla devam ettiği günümüzde de önemini korumaktadır. Ulus devletin günümüzde değişme yaşadığı şüphesiz bir gerçektir. İlk olarak ulusal siyasi formların uluslararası bir hal aldığı söylemek mümkündür. Uluslararası örgütler ve küresel sermaye, ulusal rejimlere dâhil edilmekte ve neticesinde ulusal kurumlar, politikalar ve düzenlemeler küresel siyasete göre şekillenmektedir.Ulus devletlerde meydana gelen ikinci değişiklik ise ulus üstü örgütlenmelerin ulus devletlerin sermaye birikimlerinde oynadığ artırmakta ve bununla doğru orantılı olarak yurttaşların gayri safi milli hâsıladan (GSMH) aldıkları payda artmaktadır. Son değişiklik ise ulusal siyaset ile küresel siyaset arasındaki güçlü işbirliğidir. Özellikle 1980'lerle başlayan sivil toplum örgütlenme trendi, yönetimden yönetişime geçişi zorunlu kılmakta ve özellikle yerel/alt/mikro grupların kamusal alanda görünürlüğü artmaktadır. Sonuç olarak ulus devlet ulus üstü ve ulus altı-bölgesel hareketler ile yoğrulmaktadır. Bu durum çoğu zaman ulus devletin üniter yapısını tehdit etse de bu eğilimden başka bir çıkar yol da bulunmamaktadır (Erdenöz, 1997:129-131).Bu nedenle üniter yapının mevcut gelişmeler 1şı̆̆ında federatif/bölgesel ${ }^{19}$ ya da supranasyonel ${ }^{20}$ bir yapıya doğru evirildiği gözlemlenmektedir.

Günümüzde siyasi gelişmeler en büyük zararı ulus devletlerin egemen yapısına vermiştir. Mevcut ulus devlet formu ve siyasi gelişmelerin 1şı̆̆ında ulus devletin yurttaşları ve sınırları üzerindeki hâkimiyetini kaybettiği de gözlemlenmektedir. Artık ulus devletler sınırların akışkanlığından dolayı sermayeyi, yasa dışı göçü, kültür ve tabiat varlıklarını, uyuşturucuyu ve silahı

\footnotetext{
${ }^{19} \mathrm{Bu}$ konuda örnek verilebilecek bazı ülkeler bulunmaktadır. Mikro milliyetçilikler, bölgesel grupların hareketleri neticesinde İspanya, İtalya, Fransa, İngiltere'nin yönetsel ve siyasi yapılarında değişiklikler meydana gelmiştir. Söz konusu devletler üniter yapıdan fedaratif ya da bölgesel yapıya doğru geçiş yapmışlardır. Burada vurgulanması gereken bir başka husus da bölgesel devlet ile fedaratif devletin aynı ontolojiye sahip olmadığıdır. Ayrıntılı bilgi için bknz: Atilla Nalbant, Üniter Devlet Bölgeselleşmeden Küreselleşmeye, İstanbul: On iki Levha Yayınları,2012)

${ }^{20}$ Supranasyonel yapıya verilebilecek tek örnek Avrupa Birliği’dir. Ulus devletler çeşitli antlaşmalar ile bu örgüte üye olmakta ve egemenliklerinin bir kısmını devretmektedir.
} 
kontrol edememektedir.Bunların neticesinde ulus devletler sınırlarını koruyamadığı ve meşruluğunu kaybettiği düşünülmektedir.Özellikle post moderniteninön plana çıkardığ 1 çok kültürlülük, ulus devlet içinde küçük ulus devletlerin oluşumuna zemin hazırlayan bir faktör olarak ulus devletin egemenliğini aşındırmaktadır. Ulus devlet egemenliğini bölgesel güçler, yerel gruplar, uluslararası örgüt, çok uluslu şirketler, sivil toplum kuruluşları ve supranasyonel birliklerle paylaşmakta hatta onlara devretmektedir. Tüm bunların neticesinde ulus devletler; küresel sistemlerin yerel otoriteleri ya da yerel polis-jandarma karakolları konumuna indirgenmiş(Bauman,1999:79), kendi sınırları içerisindeki ekonomik, siyasi, kültürel politikaları belirleyemez hale gelmiştir.

Ulus devletlerin siyasi sistemde geçerli devlet formu olduğunu düşünenlere karşıllk ulus devletin insanlığın en tehlikeli icadı olduğu da savunulmaktadır. Ulus devletin Weberian anlamda şiddet kullanma tekiline sahip olması onun militarist bir yapı kazanmasına neden olmuştur. Bu tezi doğrulayan istatistiklere göz atıldığında ulus devlet formunun ortaya çıkışı ve yaygınlaşması ile savaşlarda ölen insan sayısı gittikçe artmış ve bu duruma koşut olarakdünya nüfusunda azalmalar meydana gelmiştir(Yurdusev,2012:69-70, Tilly,2001:126-127). Dünya Savaşları sonrası bir daha aynı felaketi yaşamamak için ulus devletlerin meydana getirdiği uluslararası örgütlerin başarılı olmadığı görülmektedir. Ulus devlet formunun değişmesine neden olan bir diğer faktör ulus devletin "sözde" özgürlükçü yapısıdır(Yurdusev,2012:71).Milliyetçi politikalar ve üniter devletlerin merkezi politikaları ulus devletin özgürlük alanını daraltmakta ve evrensel bireysel özgürlükler kısitlanmaktadır.

Ulus devlete ilişkin yukarıda bahsedilen söz konusu durumlar ulus devletin ne tamamen ortadan kalktığı ne insanlık için bir kötülük ne de eskisinden daha güçlü bir konuma sahip olduğu anlamına gelmektedir. Ortaya çıkan yeni uluslararası model eski yapıyı tamamen ortadan kaldırabilecek nitelikte olmamakla beraber yeni model, yeni normlar, standartlar, değerler getirmektedir. Ulus devletler bu değişiklikleri absorbeederek yeni doku ve biçimleriyle evrenselliğini devam ettireceğe benzemektedir.

\section{SONUÇ}

Ulus devlet; ortak değerler konusunda uzlaşan, politika yapım sürecine katılan ve belirli bir coğrafya üzerinde yaşayan yurttaşların şekillendirdiği devlet formu olarak belirmiş ve var olduğu andan bugünesiyasi sistemin temel aktörü haline gelmiştir. Ulus devlet üç önemli öğeden oluşmaktadır. Bunlar egemenlik, ülke ve ulustur. Ulus devlet, kendisine ait sınırlar üzerinde yaşayan insanları egemenliği altında tutmakta ve devletin kendi egemenliğinden başka bir egemen güç bulunmamaktadır.

Ulus devlet, kümülatif bir sürecin sonunda ortaya çıkmıştır. İnsanlar toplumsal özellikler sergilemeye başladığı andan itibaren devlet gereksinimi ortaya çıkmış ve söz konusu devletin nasıl olmas gerektiği konusunda uzun uzadiya düşünülmüştür. Amprik olarak Ortaçağın sonlarında meydana gelse de normatif olarak ulus devlet düşüncesi ilk çağa kadar götürülmektedir. Ulus devletin kurucu unsurları aynı anda ortaya çıkmamıştır. İlk olarak feodalizmin çöküşü ile ülkesellik; daha sonra mutlak monarşilerin ortaya çıkışı egemenlik; özellikle Fransız Devrimi ile beraber ulus/ulusçuluk belirginlik kazanmıştır. Uluslararası İlişkiler disiplinine göre ulus devlet yapılanmasının 1648 Westphalia Antlaşması ile başladığı savunulsa da, bu oldukça müphem bir savdır. Çünkü ulus devletin hukuki dayanağını oluşturan bu antlaşma sonucu devletlerin uluslararası hukukun eşit öznesi haline gelmiş ve "de jure" olarak ulus devlet oluşmuştur. Ancak bu süre öncesinde ulus devlet, fiili olarak varlığını sürdürmektedir.

Ulus devlet beş farklı öğeden oluşan bir siyasi formdur. Bunlar ülkesellik, merkezilik, ulusallık, egemenlik ve siyasi yapılanmadır. Ülkesellik, ulus devletin kendine ait sınırları kesin bir 
şekilde belirli olan coğrafyayı anlatmaktadır. Sınırlar ulus devletin yaşam alanını belirleyen faktördür. Sinırlar ile ulus devletin egemenlik sahası ve demografik özellikleri belirlenmektedir. Ulus devlet, anakronik yönetim biçimlerinden farklı olarak idari ve siyasi merkeziliği sağlamıştır. Doğası gereği merkeziliğe yatkın ulus devlet bu sayede siyasi sınırları içerisinde yer alan farklı eylemleri yönlendirebilmekte, gözlemleyebilmekte, etkinleştirebilmekte ve çeşitli yaptırımlar uygulayabilmektedir. Ulus devletin oluşumunda entemel belki de en önemli enstrümanlardan bir tanesi olan ulusçuluk ise siyasi alandan toplumsal hayata, ekonomik hayattan militarist politikalara kadar ulus devletin her alanında ve anında var olmaktadır. Ulusallık temelde her devletin başka devletlere karşı kalkanı ve dayanağıdır. Ortaçağ'da ortaya çıkan egemenlik modern devletin temel paradigmasıdır. Egemenlik, belirli sınırlar içerisinde yönetme ve yönlendirme hakkıdır. Ortaya çıktığı andan itibaren ulus devletin en tartışılan öğesi olan egemenlik, aslında ulus devletin geleceğini de belirleyen ana etmendir. Kamusallık, anayasallık ve yurttaşlıktan oluşan ve yönetim ile ilişkin olan siyasi yapı, ulus devletin öznel kimliğinin ve işlevlerini ifade etmektedir. Yönetim, yönetilen ve yönetim ayrımını beraberinde getirmektedir. Yönetenlerin siyaset aktivitelerini profesyonel olarak odaklanmaları sonucu siyaset kurumsallaşmakta, toplumun tümünü kapsayan siyasi yapı oluşmakta ve devletin spesifik alanını oluşturmaktadır.

Ulus devleti gelecekte ne bekliyor? Ulus devlet için tarihin sonu mu?Yoksa evrensel siyasi bir form olarak güçlü bir şekilde devam mı edecek? Bu sorular ulus devletin dönüşümünü ve geleceğinin sorgulanması amacıyla kurgulanmaktadır. Küreselleşme karşıtlarına göremez kûr olgu ile birlikte devlet küçülmekte, zayıflamakta, otorite ile egemenliğini kaybetmekte ve uluslararasılaşarak ulus devlet buharlaşmaktadır. Küreselleşmeyi olumlayanlara göre ise ulus devletin değiştiği görmezden gelinememektedir. Ancak bu değişim ulus devletin güçlenmesine, yeni sisteme adapte olarak varlı̆̆ını sürdürmesine neden olmuştur. Küreselleşme ile devlet klasik fonksiyonlarının yanında değişik fonksiyon ve alanlar elde ederek kendini yeniden tanımlamaktadır. Küreselleşme ve ulus devlet ilişkisi ile etkileşimine yönelik bu tartışmalar, ulus devletin geleceği hakkında ipuçlarıda vermektedir. Küreselleşmenin sonucunda ulus devletin egemenliği ve sınırlar aşınmış, küresel sermaye ve organizasyonlar karşında güç kaybetmeye başlamış ve devlet yönetiminde yeni eğilimler ortaya çıkmıştır. Ulus devlet, homojenleştirici, bölünmez, devamlı ve mücerret otoriter yapıdan, daha dinamik, çok kültürlü, geçirgenbir yapıya doğru evirilmekte ve siyasi sistemin başat aktörü olma konumunu elinde bulundurmaktadır. 


\section{KAYNAKÇA}

AĞAOĞULLARI, Mehmet Ali ve Köker, Levent (2004a). Tanrı Devletinden Kral-Devlete ,Dördüncü Baskı, Ankara: İmge Yayınevi.

AĞAOĞULLARI, Mehmet Ali ve Köker, Levent (2004b). Kral Devlet ya da Ölümlü Tanrl Üçüncü Baskı, Ankara:İmge Yayınevi.

ANDERSON, Benedict(2007). Hayali Cemaatler Milliyetçiliğin Kökenleri ve Yayılması , (Çev: İskender Savaşır),Dördüncü Baskı, İstanbul: Metis Yayınevi.

ANDREW, Edward(2011). "Jean Bodin on Sovereignty." Republics of Letters: A JournalfortheStudy of Knowledge, Politics, andtheArts 2, No. 2, http://rofl.stanford.edu/node/90

ARENDT, JohannaHannah(2016). Insanlık Durumu, Çev. Bahadır Sina Şener, Sekizinci Baskı, İstanbul: İletişim Yayınları.

ARİSTOTELES (2005). Politika, Çev. Mete Tunçay,Sekizinci Baskı, İstanbul, Remzi Kitapevi.

BAĞÇE, Emre (1999). "Küreselleşme, Devlet ve Demokrasi”, Amme İdaresi Dergisi, Cilt. 32, Sayı. 4, ss.3-14

BAUMAN Zygmunt(1999). Küreselleşme, Toplumsal Sonuçları,Çev:Abdullah Yılmaz, İstanbul: Ayrıntı Yayınları.

BAYAR,Fırat(2008). "Küreselleşme Kavramı ve Küreselleşme Sürecinde Türkiye", Uluslararası Ekonomik Sorunlar Dergisi, Dışişleri Bakanlığı Yayınları, Sayı 32 http://www.mfa.gov.tr/data/kutuphane/yayinlar/ekonomiksorunlardergisi/sayi32/firatbayar.pdf

BECK, Ulrich (2000). What is Globalization, Malden: WileyBlackwellPublishers.

BERIŞ, Hamit Emrah (2008). "Egemenlik Kavramının Tarihsel Gelişimi ve Geleceği Üzerine Bir Değerlendirme Ankara Üniversitesi SBF Dergisi Cilt. 63, Sayı. 1, ss. 55-80.

BODİN Jean, "Devlet Üstüne Altı Kitap'tan Seçme Eserler" ,Mete Tuncay, Batı'da Siyasal Düşünceler TarihiCilt 2, Ankara: AÜ SBF Yayınları.

BOTTOMORE, Tom(1987). Siyaset Sosyolojisi, Çev: Erol Mutlu, Ankara: TeoriYayınları.

BRENNER, Neil(2004). New StateSpaces, Urban GovernanceandRescaling of Statehood, Oxford: Oxford UniversityPress.

CAPRA Fritjof(2003). TheHiddenConnections, London: HarperCollins.

COHEN, Edward(2001). "GlobalizationandtheBoundaries of theState: A Framework forAnalyzingtheChangingPractice of Sovereignty",GovernanceAn International Journal of PolicyandAdministration, 14(1), pp.75-97.

DAVUTOĞLU, Ahmet (2003). "Küreselleşme ve AB-Türkiye İlişkileri Çerçevesinde Ulusal Egemenliğin Geleceği” Anayasa Yargısı Dergisi, Cilt: 20, ss.46-58

EKEN, Hurigül (2006). "Küreselleşme ve Ulus Devlet", Selçuk Üniversitesi Sosyal Bilimler Enstitüsü Dergisi, Say1 16, ss. 243-262.

ERÖZDEN Ozan(1997). Ulus Devlet, Ankara: Dost Kitabevi.

ERYILMAZ Bilal(2011). Kamu Yönetimi Düşünceler, Fonksiyonlar, Yapılar, Politikalar, Dördüncü Baskı, Ankara: Okutman Yayıncılık.

ESGİN, Ali(2001). “Ulus-Devlet ve Küreselleşmeye İlişkin Bazı Tartışmalar”, Cumhuriyet Üniversitesi Sosyal Bilimler Dergisi, Cilt: 25, No: 2, ss.185-192

FLANZ Gisbert(1956). XIX Asır Avrupa'sında Anayasa Hareketleri,Çevirenler: Necat Erder, Şerif Mardin, Aydın Sinanoğlu, Ankara: Siyasal Bilgiler Fakültesi Yayınları. 
GIDDENS, Anthony(1991). Modernityand Self Identity: Self andSociety in Modern Age, Cambridge: Cambridge UniversityPress.

GÖKCE, Gülise (2007). Güçlü ve Zayıf Devlet Tartışmaları Bağlamında Türkiye, Konya: Çizgi Yayınevi

GÖZE Ayferi (2005).Siyasi Düşünceler Tarihi,Onuncu Baskıİstanbul:Beta Yayıncılık.

GÖZLER, Kemal(2007). Devletin Genel Teorisi: Bir Genel Kamu Hukuku Ders Kitabı, Bursa: Ekin Yayınevi.

HEGEL G.W.Friedrich (2003). Tarihte Akll, Çev. Önay Sözer, İkinci Basım, İstanbul: Ara Yayınları.

HELD David, McGrewAnthony, Goldblatt David, PerratonJonathan (1999). Global Transformations, Politics, EconomicsandCulture, Stanford: Stanford UniversityPress.

HEYWOOD Andrew(2013). Siyaset, Çev. B.B. Özipek vd.,Dokuzuncu Bask1, Ankara:Liberte Yayınları.

HİRST, Paul ve Thampson, Graham(1998). Küreselleşme Sorgulanıyor, Çev: Çağla Erdem ve Elif Yücel, Ankara: Dost Kitabevi. Yayınc1lik.

HOBSBAWN, Eric J. ve Terence Ranger(2006). Geleneğin İcadl, İstanbul:Agora

http://www.etymonline.com/index.php?allowed_in_frame=0\&search=nation

http://www.etymonline.com/index.php?allowed_in_frame=0\&search=state

http://www.tdvia.org/dia/ayrmetin.php?idno $=430204$

JAFFRELOT, Christopher (1998). "Bazı Ulus Teorileri", Jean, Leca (Ed), Uluslar ve Milliyetçilikler,Çev: Siren. İdemen, İstanbul: Metis Yayınları,ss. 54-65

KAPANİ, Münci(2004). Politika Bilimine Giriş, On Altıncı Baskı, Ankara: Bilgi Yayınevi.

KELLAS, James G. (1991). ThePolitics of NationalismandEthnicity, Londra:MacMillan.

KONAK Nahide," Ekonomik Küreselleşme ve Ulus-Devlet: Kuramsal Yaklaşımlar",Hacettepe Üniversitesi Edebiyat Fakültesi Dergisi, Sayı 1,(2011),ss.149-162.

KUTLU Önder, Akgün Birol, Çalış Şaban(2006). Uluslararası Örgütler, Konya:Çizgi Yayınevi.

LE GALÈS, Patrick(2006). "New State Space in Western Europe?",InternationalJournal of Urban andRegionalResearch, Volume 30, Issue 3,ss. 717-721.

LECA, Jean (1998). "Neden Söz Ediyoruz", Jean Leca (Ed), Uluslar ve Milliyetçilikler, Çev: Siren İdemen, İstanbul: Metis Yayınları,ss.11-20

MACHİAVELLİ, Nicolla(1994). Prens, Çev. Nazım Güvenç, İkinci Bask1, İstanbul: Anahtar Yayınları.

MARSHALL, Gordon(2005). Sosyoloji Sözlüğü, Ankara: Bilim ve Sanat Yayınları

MCLUHAN, Marshall ve Povers, Bruce R. (2001). Global Köy, Çev. Bahar Öcal Düzgören, İstanbul: Scala Yayıncılık.

MEYDAN Larousse (1987). Cilt: 12, İstanbul: Meydan Yayınc1lık.

NALBANT Atilla(2012). Üniter Devlet Bölgeselleşmeden Küreselleşmeye, İstanbul: On iki Levha Yayınları.

ORTAYLI, İlber(2000). “Devlet”, Doğu Batı Dergisi, Sayı 1, ss.11-16

ÖZLÜK, Erdem(2012). Uluslararası IIlişkilerde Devlet Tanım, Teori ve Devlet İstisnacılığı, Konya:Çizgi Kitapevi 
ÖZYAKIŞIR, Deniz(2006). "Ulus-Devlet ve Milli Egemenlik Bağlamında Teorik Bir Küreselleşme Eleştirisi”, Jeopolitik Dergisi, Y11: 5, Sayı:31, ss. 78-80.

PHILPOTT, Daniel (2001). Revolutions in Sovereignty: How IdeasShaped Modern International Relations, Princeton: Princeton UniversityPress.

PİERSON, Christopher (2000). Modern Devlet, Çev. Dilek Hattatoğlu, Ankara: Çivi Yazıları Yayınları.

PIETERSE, Jan Nederveen (2000).“Globalization as Hybridization”, F. J. Lechener, J. Boli (Ed) TheGlobalization, Oxford: Oxford Press.

POGGİ, Giafranco (2007). Devlet, Doğası, Gelişime ve Geleceği, İstanbul: İstanbul Bilgi Üniversitesi Yayınları

RENAN, Ernest(1996). "What Is a Nation?," (Çev. Martin Thom), GeoffEley ve Ronald GrigorSuny, Becoming National: A Reader,

Oxford/New York:

Oxford University Press, pp. 41-55.

ROKKAN, Stein(1975)."Dimensions of StateFormationandNationBuilding: A PossibleParadigmforResearch on VariationsWithin Europe", Charles Tilly(Ed.), TheFormation of NationalStates in Western Europe, Princeton : PrincetonUniversityPress, pp.562-600

SARIBAY, Ali Yaşar(1992). Siyasal Sosyoloji, Ankara: Gündoğan Yayınları.

SARIBAY, Ali Yaşar(1998).“Küreselleşme, Postmodern Uluslaşma ve İslam”, Emin Fuat Keyman ve Ali Yaşar Sarıbay (Ed). Küreselleşme Sivil Toplum ve Islam, Ankara: Vadi Yayınları,ss.14-33

SASSENSASKİA(1996). Losing Control? Sovereignty in An Age of Globalization, New York: Columbia UniversityPress.

SMITH, Anthony (1991). National Identity, Middlesax, England:Penguin Books.

ŞAHIN, Köksal(2009). Küreselleşme Tartışmaları Işı̆ğında Ulus Devlet, İkinci Baskı, İstanbul: Yeniyüzyı1 Yayınları.

TALAS,Mustafa ve Kaya,Yaşar(2007). "Küreselleşmenin Kültürel Sonuçları”, Türklük Bilimi Araştırmaları Dergisi(TÜBAR), Cilt:XXII,ss.149-162.

TEKELİ, İlhan ve İlkin, Selim(2000). "Küreselleşme Ulus-Devlet Etkileşimi Bağlamında AB-Türkiye İlişkilerinin Yorumlanması”, Doğu-Batı Dergisi, Sayı 10,ss.113-138.

TILLYCHARLES(2001). Zor, Sermaye ve Avrupa Devletlerinin Oluşumu,Çev:Kudret Emiroğlu, Ankara:İmge Yayınevi.

TİLTON, Mark (2003)." Ideas, Institutions, andInterests in theShaping of Telecommunicationsreform:Japanandthe US",Weiss, Linda (Ed). States in the Global Economy: BringingDemocraticInstitutionsBack, New York: Cambridge UniversityPress, pp. 180-199.

TUNÇAY, Mete (2002). Batı'da Siyasal Düsünceler Tarihi: Yeni Çă̆, İstanbul: İstanbul Bilgi Üniversitesi Yayınları.

UYGUN, Oktay(2003). "Küreselleşme ve Değiş̧en Egemenlik Anlayışının Sosyal Haklar Üzerine Etkisi”, Anayasa Yargısı Dergisi, Cilt. 20, ss.250-284.

WALLERSTEIN, Immanuel (1998). "Ulusal ve Evrensel: Dünya Kültürü Diye Bir Şey Olabilir Mi?” AnthonyKing(Ed.) Kültür, Küreselleşme ve Dünya-Sistemi,Çev: Gülcan Seçkin,-Ümit Hüsrev Yolsal, Ankara: Bilim ve Sanat Yayınları,ss. 121-137.

WEBERMAX(2008). Sosyoloji Yazıları (Çev.Taha Parla),On İkinci Baskı, İstanbul: Deniz Yayınları. 
WIMMER, Andreas ve MinBrian (2006). "FromEmpiretoNation-State: ExplainingWars in the Modern World, 1816-2001" AmericanSociologicalReview, 71 (6),ss. 867-897.

YURDUSEV, Ahmet Nuri (2012). "Ulus Devlet: İnsanlığın En Tehlikeli İcadı”, Tayyar Arı(Der) Uluslararası İlişkilerde Post Modern Analizler-1Kimlik, Kültür, Güvenlik ve Dış Politik,Bursa: MKM Yayıncılık, ss.59-74. 